\title{
The Foundation of Toxicology's Dose $x$ Time = Constant Paradigm in Physics
}

\author{
Karl K. Rozman ${ }^{*}$ \\ Department of Pharmacology, Toxicology and Therapeutics, University of Kansas Medical Center, 3901 Rainbow Blvd., \\ Kansas City, KS 66212, USA and GSF Institut für Toxikologie, Ingolstädter Landstr., Neuherberg, Germany
}

\begin{abstract}
The relationship dose $\mathrm{x}$ time $=$ constant $[\mathrm{mg} \cdot \mathrm{hr}]$ has been reported in many toxicological experiments during the past 100 years. It was handled as a curiosity until Rozman and Doull pointed out that it can be found in every experiment that is conducted under equilibrium conditions which is called steady state in pharmacology and toxicology. This manuscript suggests that this relationship is consistent with the most basic laws of physics.
\end{abstract}

Keywords: Dose, time, toxicology/pharmacology.

\section{INTRODUCTION}

Rozman and Doull published a series of articles on the central role of dose $\mathrm{x}$ time $=$ constant paradigm for both toxicology and pharmacology [1-7]. It was obvious from the beginning that it is a logical impossibility that a law of toxicology/pharmacology could exist on its own right rather than being a reflection of a fundamental law of nature. The simplicity of the relationship suggested that its origin must be sought in the most basic laws of physics.

\section{RATIONALE}

Dose in pharmacology/toxicology is most commonly depicted as $\mathrm{mg}$, which is a mass, whereas time is often measured as hours or days. Remembering that there is a mass/energy region where waves have properties of mass and mass (e.g. electron) has characteristics of a wave, suggested the existence of a relationship, at least for this energy region.

According to Einstein

$$
\begin{aligned}
& \mathrm{E}=\mathrm{m} \cdot \mathrm{c}^{2} \\
& \mathrm{~m} . . . \mathrm{mass}[\mathrm{g}] \\
& \mathrm{c} . . . . \mathrm{velocity} \text { of light }\left[\mathrm{cm} \cdot \mathrm{sec}^{-1}\right]
\end{aligned}
$$

and according to Planck

$$
\begin{aligned}
& \mathrm{E}=\mathrm{h} \cdot \mathrm{v} \\
& \mathrm{h} . . . \text { Plank's action constant }
\end{aligned}
$$$$
\text { (Wirkungsquantum) [erg } \cdot \mathrm{sec}]
$$$$
v(\mathrm{nu}) \text {...frequency of radiation (light) }\left[\mathrm{sec}^{-1}\right] \text {. }
$$

Consequently for the same level of energy $(E=$ constant $)$ it must be valid to write

$$
\begin{aligned}
& \mathrm{m} \cdot \mathrm{c}^{2}=\mathrm{h} \cdot \mathrm{v} \\
& \text { or } \\
& \mathrm{m}=\frac{h}{c^{2}} \cdot \mathrm{v} .
\end{aligned}
$$

\footnotetext{
*Address correspondence to this author at the Department of Pharmacology, Toxicology and Therapeutics, University of Kansas Medical Center, 3901 Rainbow Blvd., Kansas City, KS 66212, USA; Tel: 913-588-7717; Fax: 913-588-7501; E-mail: krozman@kumc.edu
}

Since both $h$ and $c$ are constants they yield a new constant

$$
\begin{aligned}
\mathrm{m} & =\text { constant }^{*} \cdot v \\
\text { or } \quad \frac{m}{v} & =\text { constant* }[\mathrm{g} \cdot \mathrm{sec}]
\end{aligned}
$$

It was astonishing to see the dimensions of the dose $\mathrm{x}$ time $=$ constant paradigm of toxicology/pharmacology emerging from these basic considerations.

\section{COMMENTS}

The similarity of the defraction spectrum of electrons and of X-rays of similar energy on, for example, aluminum powder, was textbook knowledge back in the 1960s [8], suggesting that at least in terms of energy they are indeed identical. The dose $\mathrm{x}$ time $=$ constant paradigm of toxicology/pharmacology has been reported under various experimental conditions during the past 100 years, most often in inhalation toxicology. It has not been recognized though until Rozman et al. [6,7] pointed out that the fundamental requirement for it was that it could be seen only, but then always, under conditions of equilibrium or in the language of pharmacology/toxicology under conditions of pharmacokinetic or pharmacodynamic steady state.

\section{DISCUSSION}

To have a foundation in fundamental laws of nature is enormously important for any scientific discipline. So it is for toxicology and pharmacology, because it carries the potential of the dose $\mathrm{x}$ time $=$ constant paradigm to be elevated to a theory. A theory has far-reaching consequences for a discipline because it defines the boundaries of what is possible and what is impossible like thermodynamics did it for those seeking to construct various kinds of perpetuum mobile. Toxicology has more than its fair share of unfounded speculations devouring enormous resources due to the resulting irrational regulations. Linear extrapolation of toxicity (carcinogenicity) is perhaps to most striking example among many. If this hypothesis attains the level of a theory of toxicology, then many of its current practitioners will join up with the now extinct crowd of searchers for a perpetuum mobile, this time around of the toxicological kind. 


\section{REFERENCES}

[1] Rozman, K.K.; Doull, J. Dose and time as variables of toxicity. Toxicology, 2000, 144, 169-178.

[2] Rozman, K.K.; Doull, J. The role of time as a quantifiable variable of toxicity and the experimental conditions when Haber's c x t product can be observed: implications for therapeutics. J. Pharmacol. Exper. Ther., 2001, 296, 663-668.

[3] Rozman, K.K.; Doull, J. Paracelsus, Haber and Arndt. Toxicology, 2001, 160, 191-196.

[4] Rozman, K.K.; Lebofsky, M.; Pinson, D.M. Chronic toxicity and carcinogenicity of 1,2,3,4,6,7,8-heptachlorodibenzo-p-dioxin displays a distinct dose/time toxicity threshold $(\mathrm{c} \times \mathrm{t}=\mathrm{k})$ and a life- prolonging subthreshold effect. Food Chem. Toxicol., 2005, 43, 729-40.

[5] Saghir, S.A.; Lebofsky, M.; Pinson, D.M.; Rozman, K.K. Validation of Haber's Rule (dose $\mathrm{x}$ time $=$ constant $)$ in rats and mice for monochloroacetic acid and 2,3,7,8-tetrachlorodibenzo-p-dioxin under conditions of kinetic steady state. Toxicology, 2005, 215, 48-56.

[6] Rozman, K.K.; Doull, J.; Hayes, W.J., Jr. In Handbook of Pesticide Toxicology, $2^{n}$ ed.; R. Krieger, Ed. In Chief; Academic Press, San Diego, 2001, Vol. 1, pp. 1-93.

[7] Rozman, K.K.; Roth, W.J.; Doull, J. In Toxicology of the Lung, Target Organ Toxicology Series, $4^{\text {th }}$ ed. . Gardner, D.E. Ed.; Taylor and Francis, 2006, pp. 195-226.

[8] Ulich, H.; Jost, W. In Kurzes Lehrbuch der Physikalischen Chemie; D.S. Verlag, Ed.; Damstadt, Germany, 1963, pp. 288-356.

(C) Karl K. Rozman; Licensee Bentham Open.

This is an open access article licensed under the terms of the Creative Commons Attribution Non-Commercial License (http://creativecommons.org/licenses/by$\mathrm{nc} / 3.0 /$ ) which permits unrestricted, non-commercial use, distribution and reproduction in any medium, provided the work is properly cited. 